\title{
PERUBAHAN STATUS RADIO REPUBLIK INDONESIA DALAM PENGEMBANGAN KAPABILITAS DARI MILIK PEMERINTAH MENJADI MILIK PUBLIK
}

\author{
Nellis Mardhiah \\ Fakultas Ilmu Sosial dan Ilmu Politik, Universitas Teuku Umar \\ Email: nellismardhiah@gmail.com
}

\begin{abstract}
Abstrac
The aim of this study was to investigate changes RRI Status of Government Owned Public Being Held Under Law No. 32 of 2002 on Broadcasting. RRI and Broadcasting independent, neutral, non-commercial and works to serve the needs of society. This study uses a qualitative method to collect data, data reduction, data presentation and conclusion or data verification. The theory used is the Change in Status and Development Board. Subjects in this study is the snowball sampling is RRI officials and community leaders as a stimulus of RRI. The results showed that the cause of the change in status due to the demands of RRI bureaucratic reform, RRI own internal demands and also supported by external parties as well as the demands of Act No. 32 of 2002 on broadcasting survey and observation approach openly with previous studies and various print and electronic media sources. The obstacles faced by RRI in adapting to their status as LPP derived from internal RRI it self and also from outside RRI. Human Resources is a constraint on the internal RRI are generally accustomed to rule by the government. From among the external number of listeners of RRI relatively little, but RRI continues to struggle extra to broadcast to the public interest, RRI as public broadcasting institution that bears the name of the state is required to be implemented in accordance with the duties and functions that have been entrusted to him as stipulated in Law No. 32 in 2002, Government Regulation No. 11 of 2005 and Government Regulation No. 12 of 2005.
\end{abstract}

Keywords: Status RRI, by that Government, Public Owned

\section{PENDAHULUAN}

Perubahan adalah sebuah keniscayaan ini terjadi pada semua aspek kehidupan kita, tidak terkecuali pada sebuah lembaga penyiaran ter besar dan tertua di Indonesia yakni Radio Republik Indonesia (RRI).

RRI adalah satu-satunya radio yang menyandang nama negara yang siarannya ditujukan untuk kepentingan bangsa dan negara. RRI sebagai Lembaga Penyiaran Publik yang independen, netral dan tidak komersial yang berfungsi memberikan pelayanan siaran informasi, pendidikan, hiburan yang sehat, kontrol sosial, serta menjaga citra positif bangsa di dunia internasional.

RRI sebagai media penyiaran paling tua di negeri ini harus ikut memainkan peran dan disinilah tugas Dewan Pengawas LPP RRI masa jabatan 2015-2020 menjadi sangat penting dan strategis. Di satu sisi harus ikut terlibat memberikan masukan serta komunikasi 
aktif dengan pihak legislatif serta jajaran Dewan Direksi guna memastikan RUU Radio dan Televisi ini bisa memenuhi aspirasi RRI dan menjadi sebuah Lembaga Penyiaran yang kuat dan mandiri.

Sementara di sisi lain Dewan Pengawas LPP RRI harus juga menyusun kebijakan umum dan rencana induk yang komprehensif untuk memastikan konsistensi dan keberlangsungan lembaga penyiaran ini dalam masa 5 tahun ke depan dalam melayani publik di tengah berbagai perubahan yang akan terjadi.

Pada tahun 2000 Radio Republik Indonesia (RRI) beralih status menjadi Perusahaan Jawatan (PERJAN) sesuai dengan Peraturan Pemerintah Nomor 37 Tahun 2000 Tentang Pendirian Perusahaan Jawatan Radio Republik Indonesia, didalam peraturan pemerintah ini Radio Republik Indonesia berada dalam ruang lingkup Departemen Keuangan. Perusahaan Jawatan memiliki tanggung jawab social yang tinggi yaitu, pelayanan publik dan tidak semata-mata mencari keuntungan, modal perusahaan tidak dipisahkan artinya modal semua dimiliki oleh pemerintah dan tidak terbagi atas sahamsaham. Status sebagai perusahaan jawatan membuat Radio Republik Indonesia melakukan perubahan mendasar dalam visi dan misinya yang tercantum dalam pasal 6 (enam) Peraturan Pemerintah Nomor 37 Tahun 2000 yang berbunyi "Maksud dan tujuan PERJAN adalah menyelenggarakan kegiatan penyiaran radio sesuai dengan prinsip-prinsip radio publik yang independen, netral, mandiri dan program siarannya senantiasa berorientasi kepada kepentingan masyarakat, serta tidak semata-mata mencari keuntungan".

Sejak diberlakukannya Undang-Undang Nomor 32 Tahun 2002 tentang Penyiaran dan Peraturan Pemerintah Nomor 12 Tahun 2005 tentang Lembaga Penyiaran Publik (LPP) Radio Republik Indonesia (RRI), hingga sekarang masih ada beberapa isi dalam kedua kebijakan tersebut yang belum dilaksanakan secara optimal seperti aspek kelembagaan, dan program di Radio Republik Indonesia, dimana kedua aspek tersebut sangat penting dalam melihat perkembangan Radio Republik Indonesia sebagai Lembaga Penyiaran Publik. Pada pasal 14 Undang-Undang Nomor 32 tahun 2002 ditegaskan bahwa RRI adalah LPP yang bersifat independen, netral, tidak komersil dan berfungsi melayani kebutuhan masyarakat.

Tugas berat yang diemban Lembaga Penyiaran Publik (LPP) harus dibarengi dengan perubahan tata kelola organisasi, dan transformasi teknologi penyiaran. Transformasi ini merupakan konsekuensi dari perkembangan teknologi digital, perubahan pasar lewat gejala internasionalisasi dan konsentrasi, melemahnya pengaruh politik pemerintah dan parlemen, serta perubahan perilaku pengguna; dari passive mass audience kepada interactive individual. Christian S.Nissen, (2006:8-12). Inilah tugas penting Dewan Pengawas LPP RRI Menjawab berbagai tantangan perubahan zaman karena perubahan adalah keniscayaan.

\section{METODE PENELITIAN}

Jenis penelitian dalam penelitian ini adalah penelitian kualitatif dengan pendekatan fenomenologi. Pendekatan fenomenologi sengaja digunakan untuk mengungkap data abstrak dan simbolik dengan tujuan utama memahami gejala yang muncul sebagai suatu kesatuan yang utuh, dengan memiliki konsep dasar kompleksitas atau realitas suatu masalah yang disebabkan oleh perspektif subjek. 
Dalam menentukan subjek penelitian peneliti menggunakan teknik snowball sampling sebagai informan utama adalah Camat dan Geucik dipilih dianggap keterwakilan dari beberapa Gampong, serta mampu meberikan informasi dari proses pelaksanaan sosialisasi. Beberapa anggota tuha peut di Gampong dan tokoh masyarakat sejumlah 3 orang sebagai bagian dari tokoh pemuda.

Metode pengumpulan data dalam penelitian ini menggunakan teknik dan wawancara dan observasi serta dokumentasi. Analisa data yang dilakukan berdasarkan hasil interpretasi berdasarkan hasil fenomena sosial sebagai upaya dalam mendeskripsikan hasil penelitian.

\section{HASIL DAN PEMBAHASAN}

\section{Konsep Perubahan Status dan Pengembangan Lembaga}

Perubahan organisasi adalah suatu proses dimana organisasi tersebut berpindah dari keadaannya yang sekarang menuju ke masa depan yang diinginkan untuk meningkatkan efektifitas organisasinya. Tujuan perubahan adalah untuk mencari cara baru atau memperbaiki dalam menggunakan resources dan capabilities dengan tujuan untuk meningkatkan kemampuan organisasi dalam menciptakan nilai dan meningkatkan hasil yang diinginkan kepada stakeholder

Menurut Pasmore (1994:3) dalam Wibowo (2011:104), menyatakan bahwa perubahan dapat terjadi pada diri kita maupun di sekeliling kita, bahkan kadang-kadang kita tidak sadari bahwa hal tersebut berlangsung. Perubahan berarti bahwa kita harus berubah dalam cara mengerjakan atau berfikir tentang sesuatu, yang dapat menjadi mahal dan sulit. Perubahan adalah sesuatu yang tidak dapat dihindari karena dorongan eksternal dan karena adanya kebutuhan internal. Semua organisasi menghadapi lingkungan yang dinamis dan berubah, lingkungan eksternal organisasi cenderung merupakan kekuatan yang mendorong untuk terjadinya perubahan, ada banyak factor yang bisa membuat dibutuhkannya tindakan perubahan. Disisi lain bagi organisasi secara internal merasakan adanya kebutuhan akan perubahan. Oleh karena itu, setiap organisasi menghadapi pilihan antara berubah atau mati tertekan oleh kekuatan perubahan.

Perubahan yang terjadi dalam suatu organisasi biasanya direncanakan oleh para stakeholder yang terdapat dalam organisasi tersebut yang bertujuan untuk mengembangkan organisasi seperti yang dikemukakan oleh J. Winardi (2005:82), bahwa suatu organisasi yang menginginkan keberhasilan harus terus-menerus melakukan perubahan sebagai bentuk reaksi dari perkembangan-perkembangan yang sifatnya penting, seperti kebutuhan pemerintah. Selain itu masih menurut J. Winardi (2005:5) yang mengutip pernyataan Sweeney Mc Farlin bahwa terdapat tipe perubahan yang berguna bagi perkembangan suatu organisasi, yaitu berupa strategi yang dapat mencakup pada postur pertumbuhan, pendekatan berbalik arah, penarikan diri dan stabilisasi. 


\section{Pengembangan Lembaga}

Tercapainya tata pemerintahan yang baik (good governance) tercermin melalui indicator perilaku pemerintah dalam menjalankan kewenangan, tanggung jawab dan kewajiban pelayanan publiknya memenuhi prinsip-prinsip partisipasi, efisiensi dan efektifitas, keadilan, akuntabilitas, serta transparansi. Agus Dwiyanto (2008:102). Untuk mencapai tata kepemerintahan yang baik (good governance) diperlukan upaya-upaya perubahan mindset dan culture-set pemerintah melalui upaya pengembangan lembaga yang mencerminkan nilai-nilai good governance. Pengembangan lembaga adalah suatu perencanaan, penataan dan bimbingan untuk:

a. Mewujudkan perubahan-perubahan dalam nilai-nilai, fungsi-fungsi, teknologiteknologi fisik dan sosial.

b. Menetapkan, mengembangkan dan membina hubungan-hubungan normative dan pola-pola tindakan yang baru.

c. Membina jejaring atau kaitan-kaitan untuk memperoleh dukungan dan kelengkapan dari lingkungannya.

Mengandalkan diri pada sentralitas peran public sebagai inisiator perubahan selain akan mengaburkan tanggung jawab dan kewajiban pemerintah pada publiknya, juga butuh waktu panjang, mengingat kondisi masyarakat yang sangat heterogen dalam tingkat pendidikan dan status sosialnya. Ide atau inisiator perubahan bisa berasal dari dua pihak: pemerintah atau masyarakat. Inovasi dari publik diperkuat oleh pemerintah melalui kewenangannya, sehingga inovasi itu dapat hidup dan tumbuh terus. Inovasi dari pemerintah diuji dan dikontrol oleh publik agar tetap dalam koridor nilai-nilai dan normanorma lokal maupun yang bersifat universal (keadilan, kejujuran, misalnya). Bukankah menumbuhkan budaya governance dan publik service tidak dapat berlangsung dalam lingkungan yang steril dan terasing satu sama lain? Mengadaptasi model universum pengembangan lembaga yang dikembangkan oleh Esman, maka proses pengembangan lembaga good governance dan good public service tampak dalam unsur-unsur variabel lembaga sebagai berikut:

\section{1) Kepemimpinan}

Kepemimpinan adalah kelompok orang yang secara aktif terlibat dalam merumuskan doktrin dan program lembaga, mengarahkan aktifitas-aktifitas lembaga serta menetapkan dan membina hubungan-hubungan dengan lingkungannya. Dalam kaitannya dengan pengembangan mind-set dan culture-set governance, maka kepemimpinan terutama sekali minimal menunjuk kepada sosok atau figur kepala daerah. Kualitas kepemimpinan sangat penting artinya, terutama sekali bagi Negara kita yang cenderung bersifat paternalistic dan membutuhkan keteladanan dalam pola bertindak. Pemimpin yang dibutuhkan untuk mengembangkan mindset dan culture-set governance di daerah setidaknya memilik 4 (empat) C, yaitu: 1) concept, yakni memiliki kerangka berfikir, visi, misi dan program yang jelas, 2) competence, yakni perpaduan knowledge, skills, attitude yang diperlukan untuk meningkatkan kualitas pelayanan public, 3) commitment pada tugas dan fungsinya yang dapat dibuktikan, 4) consistent. Effendy (2005). Fungsi penting kepemimpinan dalam model kelembagaan ini adalah mengenali, membina dan memperluas 
jejaring yang terkait dengan tujuan lembaga. Melalui proses transaksi yang intensif dengan lingkungan, jejaring itu dapat dikenali, dibina dan diperluas.

\section{2) Doktrin}

Doktrin adalah merupakan nilai-nilai/tujuan-tujuan/metode-metode operasional yang mendasari tindakan sosial, yang menggambarkan citra dan harapan-harapan yang dituju. Doktrin yang mendasari tindakan operasional kepemerintahan tentu saja yang mewakili nilai-nilai good governance, yakni pelayanan public dengan prinsip: partisipasi, efisiensi dan efektifitas, keadilan, akuntabilitas dan transparansi. Dwiyanto, (2008:102).

\section{3) Program}

Program adalah aktifitas-aktifitas pelaksanaan dari fungsi yang diemban oleh lembaga, atau yang merupakan output dari lembaga tersebut. Program-program adalah setiap aktifitas/kegiatan pemerintahan yang dirancang untuk mewujudkan kesejahteraan publik melalui pengelolaan barang dan layanan publik yang memenuhi hak-hak dasar manusia. Untuk itu penyusunan isi program/kebijakan harus memenuhi indikator pertimbangan etika yakni: manfaat, pemenuhan hak, keadilan dan pemeliharaan/keberlanjutan. Griffin \& Ebert dalam James AF Stoner (1996:124) dan indikator pelayanan publik, yaitu: 1) efektivitas program, 2) produktivitas keluaran yang dibutuhkan masyarakat, efisiensi, dan kepuasan. Ratminto \& Atik, (2005:2). Dari segi operasionalnya mampu memenuhi criteria kelayakan ekonomi, teknis dan administrasi (INTERPLAN: 1969). Sebaliknya dalam proses delivery (penyampaian) program/kebijakan pada publik juga harus memenuhi kriteria kinerja pelayanan yang diukur dari: 1) keadilan dan persamaan pelayanan, 2) kepastian waktu dan biaya menurut standar efisiensi 3) responsivitas, dan 4) suap/rente birokrasi. Dwiyanto, (2006:50).

\section{4) Sumber Daya}

Sumber daya adalah input berupa SDM, dana, sarana fisik dan teknologi yang dibutuhkan oleh lembaga dalam menjalankan aktifitasnya. Pada umumnya yang dituding menjadi kendala dalam pelaksanaan program adalah keterbatasan kualitas dan kuantitas sumber daya (SDM, dana, sarana fisik, dan teknologi) di daerah. Namun dengan kepemimpinan yang baik dan berkomitmen dan berkreatifitas tinggi, kendala-kendala demikian dapat diatasi dalam banyak cara.

Selain itu apabila konsep tentang sumber daya tidak dibatasi hanya dengan apa yang de facto yang ada di pemerintah daerah, tapi juga semua potensi yang mungkin dimiliki daerah. Dengan kreatifitas pimpinan yang mampu melihat dan membina jejaring dengan seluruh potensi sumber daya yang ada di daerah, maka sumber daya bisa jadi tak terbatas lagi. Upaya ini bisa ditempuh dengan membina jejaring pada dunia usaha dan LSM-LSM terkait, dalam bentuk: partnership, outsourching atau komersialisasi dan koorporatisasi bidang-bidang tertentu yang mungkin dilakukan tapi tidak mengalihkan tanggung-jawab utama pemerintah pada publik apalagi mengorbankan kepentingan publik.

\section{5) Struktur Intern}

Struktur organisasi lembaga berupa wewenang formal dan informal, pembagian kerja, saluran komunikasi dan proses-proses yang dibuat baru atau disusun kembali agar lembaga tersebut dapat berfungsi dan terpelihara keberlangsungannya. Yang dimaksud 
sebagai struktur intern ini adalah pola hubungan antar pelaku dalam pemerintahan untuk men-delivery program layanan publik yang diemban lembaga. Pembentukan struktur intern ini harus disesuaikan dengan kebutuhan efektifitas delivery program dalam masyarakat. Karenanya lembaga tidak harus berbentuk organisasi dengan struktur formal yang ketat, namun bisa bersifat informal, lentur, sementara atau bahkan berwujud mekanisme, prosedur dan jaringan. Dwiyanto, (2003:128).

\section{Undang-Undang Nomor 32 Tahun 2002}

Undang-Undang Nomor 32 Tahun 2002 tentang Penyiaran, RRI saat ini berstatus Lembaga Penyiaran Publik (LPP). Pasal 14 Undang Undang Nomor 32 tahun 2002 menegaskan bahwa RRI adalah LPP yang bersifat independen, netral, tidak komersil dan berfungsi melayani kebutuhan masyarakat. Perubahan ini menyebabkan pergeseran peran RRI, dari yang semula government oriented menjadi public oriented. RRI sebagai LPP juga dituangkan dalam Peraturan Pemerintah Nomor 11 dan 12 Tahun 2005 penjabaran lebih lanjut dari Undang-Undang Nomor 32 tahun 2002. Perubahan RRI menjadi LPP telah melampaui proses yang cukup panjang, dimulai dari semangat perubahan yang berawal dari internal RRI yang menganggap bahwa sudah tidak masanya lagi sebuah radio sebagai corong pemerintah, sosialisasi perubahan ke pihak eksternal, mengadakan kajian-kajian bersama dengan pakar hukum dan komunikasi, dan dengan pemantapan status RRI agar disahkan dalam Undang-Undang, sampai akhirnya RRI saat ini menyandang status sebagai LPP.

\section{Analisis Penyebab Perubahan Status RRI}

RRI adalah lembaga yang mengalami perubahan status, perubahan tersebut adalah peralihan dari Perusahaan Jawatan menjadi Lembaga Penyiaran Publik yang merupakan salah satu badan hukum yang didirikan oleh Negara dan berdasarkan Peraturan Pemerintah (PP) Nomor 12 tahun 2005, dan berkedudukan langsung di bawah Presiden Republik Indonesia, artinya RRI bertanggung jawab langsung kepada Presiden atas segala aktivitasnya.

Berdasarkan informasi yang diperoleh dari Kepala Stasiun RRI Meulaboh, maka dapat dianalisis jika penyebab perubahan status RRI disebabkan oleh tiga faktor, yaitu sebagai berikut:

1. Tuntutan Reformasi Birokrasi, reformasi birokrasi di Indonesia menandakan beralihnya sistem pemerintahan di Indonesia yang semua otoriter menjadi demokrasi. Sistem pemerintahan yang berubah membuat pemerintah kehilangan hak istimewanya untuk menyetir RRI.

2. Tuntutan perubahan internal (dorongan dari dalam diri RRI), selain tuntutan reformasi, tutuntutan internal RRI yang menjadi motor penggerak paling berpengaruh dalam perubahan status RRI. Para pemimpin RRI menyedari pergeseran peran RRI yang semua didirikan sesuai dengan Tri Prasetya, malah menjadi sarana yang dikuasai oleh satu golongan.

3. Tuntutan eksternal, yaitu para akademisi yang menjadi penggerak RRI sebagai LPP. Para akademisi ini mengadakan kajian-kajian supaya RRI berubah. Melakukan kerjasama dengan IFES, mengadakan seminar di berbagai kota untuk 
pengenalan LPP.

4. Tuntutan Undang-Undang nomor 32 tahun 2002 tentang penyiaran, dengan disahkannya Undang-Undang nomor 32 tahun 2002 tentang Penyiaran, RRI saat ini berstatus Lembaga Penyiaran Publik (LPP). Pasal 14 Undang Undang Nomor 32 tahun 2002 menegaskan bahwa RRI adalah LPP yang bersifat independen, netral, tidak komersil dan berfungsi melayani kebutuhan masyarakat. Perubahan ini menyebabkan pergeseran peran RRI, dari yang semula government oriented menjadi public oriented. RRI sebagai LPP juga dituangkan dalam Peraturan Pemerintah Nomor 11 dan 12 Tahun 2005 penjabaran lebih lanjut dari Undang-Undang Nomor 32 tahun 2002. Perubahan RRI menjadi LPP telah melampaui proses yang cukup panjang, dimulai dari semangat perubahan yang berawal dari internal RRI yang menganggap bahwa sudah tidak masanya lagi sebuah radio sebagai corong pemerintah, sosialisasi perubahan ke pihak eksternal, mengadakan kajian-kajian bersama dengan pakar hukum dan komunikasi, dan dengan pemantapan status RRI agar disahkan dalam Undang-Undang, sampai akhirnya RRI saat ini menyandang status sebagai LPP.

Pencapaian yang dicapai saat ini, bukanlah hal yang mudah untuk diraih, RRI memperjuangkan hal tersebut. RRI memperjuangkan status LPP yang saat ini mereka sandang dengan upaya dan kerja keras yang luar biasa. Dimulai dengan semangat Tri Prasetya yang kembali berkibar dikalangan internal RRI, lalu mengadakan kajian-kajian dan seminar-seminar untuk mendapatkan masukan dan kritikan dari pihak akademisi, badan hukum, LSM dan pakar- pakar intelektual, hal ini dilakukan agar RRI bisa berubah dan berkembang sesuai dengan apa yang dibutuhkan oleh publik, dibutuhkan bukan diinginkan. Setelah melakukan berbagai macam pendekatan ke eksternal dan memantapkan diri, barulah RRI bergerak maju ke DPR/ Komisi I intuk memperjuangkan status RRI. Pendekatan dan lobi-lobi terus dilakukan RRI mengenai pentingnya mereka berubah status. Pada akhirnya dengan perjuangan yang ekstra keras, maka disahkan RRI dalam UndangUndang sebagai LPP. Dengan disahkan Undang-Undang tersebut, maka RRI telah menyandang predikat baru sebagai lembaga yang independen, netral dan tidak komersil.

LPP RRI saat ini memiliki landasan idiilnya adalah Undang-Undang nomor 32 tahun 2002 tentang penyiaran, Peraturan Pemerintah nomor 11 tahun 2005 tentang lembaga penyiaran publik dan Peraturan Pemerintah nomor 12 tahun 2005 tentang Lembaga Penyiaran Publik Radio Republik Indonesia. Secara teknis operasional RRI senantiasa melakukan perubahan-perubahan menyesuaikan dengan kebutuhan masyarakat dalam bidang informasi, hiburan, berita dan siaran budaya serta siaran-siaran keagamaan. Dari beberapa landasan ini yang kemudian RRI berani melakukan terobosan untuk melakukan perubahan.

Perubahan RRI menjadi LPP pada dasarnya mendapatkan dukungan dari beberapa pihak, pakar hukum, pakar komunikasi dan teknologi, sehingga tidak terjadi permasalahan yang begitu mencolok dalam menjalani perubahan. Dengan dilandasi semangat TRI Prasetya RRI maka seluruh angkasawan/angkasawati yang telah dipersiapkan RRI, harus bisa beradaptasi dengan berbagai perubahan RRI. Secara operasional siaran perubahan status RRI yang menjadi LPP, tidak menjadi hambatan yang dapat menghentikan langkah RRI, karena semua kegiatan penyiarannya dan pelayanannya kepada publik merujuk pada 
rencana induk yang telah ditetapkan oleh Dewan Pengawas RRI dan diterjemahkan landasan operasionalnya melalui Peraturan Direksi.

\section{Analisis Kendala yang Dihadapi RRI Dalam Menyesuaikan Diri dengan Statusnya Sebagai LPP.}

Tentu tidak sedikit kendala-kendala yang dihadapi RRI dalam menyesuaikan diri dengan statusnya sebagai LPP, Berdasarkan hasil penelitian yang peneliti lakukan ada dua kendala yang dihadapi RRI yakni:

\section{Kendala Internal}

Sumber Daya Manusia merupakan kendala internal RRI. Dalam menyesuaikan diri dengan perubahan statusnya sebagai LPP, RRI terus berusaha untuk meningkatkan SDM nya. Dari hasil wawancara dengan Kepala sub bagian Tata Usaha RRI Stasiun Meulaboh, terlihat jelas bahwa RRI melakukan peningkatan SDM dengan cara internasionalisasi, yaitu bekerjasama dengan radio Swedia untuk mengadakan pelatihan. Pelatihan terhadap internal RRI dimaksudkan untuk merubah pola pikir dan memaksimalkan kinerja SDM dalam menyesuaikan diri dengan perubahan yang mereka alami. Pelatihan ini sangat efektif jika meranah kebelakang, ketika RRI menjadi corong pemerintah. Corong pemerintah dengan kata lain RRI dituntut untuk menuruti keinginan pemerintah, hal ini yang menyebabkan banyak internal RRI yang terbiasa untuk disuapi, sedangkan perubahan status menjadi LPP berarti menuntut internal RRI untuk lebih kreatif. upaya yang dilakukan dan tak pernah berhenti sampai disitu, RRI secara terus menerus melakukan perbaikan SDM dengan menyelenggarakan pelatihan penyiaran, pemasaran, pemberitaan dan ketatausahaan baik di dalam maupun di luar Negeri.

\section{Kendala Eksternal}

Adapun yang menjadi kendala eksternal RRI adalah, RRI saat ini memiliki pendengar yang cukup sedikit jika dibandingkan dengan radio swasta, dapat dianggap bahwa RRI kurang menarik bagi pendengar, hal ini memang tidak berpengaruh banyak terhadap keuangan RRI, namun akan menjadi sia-sia jika suatu hal yang sangat bagus dan dirasa bermanfaat tetapi tidak terlalu dihiraukan oleh masyarakat. Mengingat RRI menggunakan APBN dan APBD. Hal inilah yang menjadi salah satu kelemahan RRI, namun baru-baru ini RRI melakukan kegiatan Respon Data Pendengar (RDP) hal ini dilakukan untuk mendata seberapa banyak masyarakat yang mendengarkan siaran RRI serta melakukan perbaikan terhadap kualitas siaran RRI. Ini juga sejalan dengan penyataan Kepala Stasiun RRI Meulaboh yang menyatakan bahwa RRI adalah radio berkualitas tinggi yang tidak begitu saja berubah mengikuti pasar. RRI adalah radio yang menjaga harkat dan martabat NKRI, jadi tidak selayaknya Radio Negara yang disiarkan sampai ke mancan Negara mengikuti selera pasar yang berubah-ubah, misalnya hanya mengiginkan lagu-lagu saja, atau hanya titip salam terus-menerus. Belum lama ini RRI juga telah melakukan kegiatan Respon Data Pendengar (RDP) untuk mendata berapa banyak masyarakat yang mendengarkan RRI sekaligus memberi respon terhadap pertanyaan, saran, kritik bahkan komentar dari pendengar RRI. 


\section{KESIMPULAN DAN SARAN}

Berdasarkan uraian yang telah dijelaskan dalam skripsi ini maka dapat disimpulkan sebagai berikut :

1. Penyebab perubahan status RRI ini terjadi karena adanya tuntutan dari: reformasi birokrasi, pihak internal, pihak eksternal dan UU nomor 32 tahun 2002 tentang penyiaran. Semangat perubahan yang muncul dari internal RRI karena adanya keinginan untuk melayani publik yaitu pemerintah dan masyarakat secara umum.

2. Undang-Undang Nomor 32 tahun 2002 tentang penyiaran dan PP Nomor 11 dan 12 tahun 2005 merupakan landasan hukum RRI sebagai Lembaga Penyiaran Publik yang bersifat independen, netral dan tidak bersifat komersial yang tugasnya memberikan pelayanan siaran informasi, pelestarian budaya, pendidikan, hiburan yang sehat, kontrol sosial dan menjaga citra positif bangsa di dunia Internasional.

3. Kendala yang dihadapi RRI dalam menyesuaikan diri dengan statusnya sebagai LPP berasal dari internal RRI sendiri dan juga dari luar RRI. Adapun kendala internalnya adalah sumber daya manusia. Sedangkan kendala eksternalnya adalah jumlah pendengar RRI yang relatif sedikit.

\section{Saran}

Untuk memberikan hasil yang maksimal terhadap perubahan status RRI dari Milik Pemerintah menjadi Milik Publik berdasarkan UU Nomor 32 tahun 2002 tentang penyiaran maka perlu kiranya penulis memberikan saran sebagai berikut:

1. Melihat kondisi saat ini RRI sudah menjadi milik publik, harapan penulis agar RRI terus memperhatikan kondisi lingkungan internal RRI dengan cara melakukan pelatihan-pelatihan untuk meningkatkan kemampuan sumber daya manusianya.

2. Dalam memberikan pelayanan informasi, penulis juga berharap agar RRI dapat menghadirkan program-program siaran yang menyentuh langsung terhadap kepentingan informasi yang dibutuhkan masyarakat sehingga siaran RRI semakin diminati oleh masyarakat.

3. Dalam menyesuaikan diri dengan status sebagai LPP, penulis mengharapkan agar RRI dapat menyelesaikan permasalahan internalnya terutama sistem kerjasama yang baik antar sesama angkasawan/ti baik itu Aparatur Sipil Negara (ASN) dengan tenaga kontrak maupun sebaliknya, sehingga bisa saling menghargai dan tidak mengedepankan ego masing-masing dalam bekerja.

\section{DAFTAR PUSTAKA}

Arikunto, Suharsimi. 2002. Prosedur Penelitian Suatu Pendekatan Praktek. Jakarta. Rineka Cipta. 
Dwiyanto, Agus. dkk. 2003. Reformasi Tata Pemerintahan dan Otonomi Daerah. Yogyakarta: Pusat Studi Kepedudukan dan Kebijakan Universitas Gadjah Mada.

Dwiyanto, Agus. 2008. Mewujudkan Good Governance Melalui Pelayanan Publik. Yogyakarta. Gadjah Mada University Press.

Hasan, Ikbal. 2002. Metodologi Penelitian Kualitatif. Bandung. PT. Remaja Rosdakarya.

Jogiyanto. 2005. Sistem Informasi Strategik Untuk Keunggulan Kompetitif. Yogyakarta. Andi Offset.

International Group for National Planning (INTERPLAN). Appraising Administrative Capability for Development. (New York: United Nations, 1969).

James AF Stoner, dkk. 1996. Manajemen, edisi Indonesia. Jakarta. PT. Prehallindo.

Moleong, Lexy. 2002. Metodologi Penelitian Kualitatif. Bandung. PT. Remaja Rosdakarya.

Mufid, Muhamad. 2007. Komunikasi \& Regulasi Penyiaran. Jakarta. Prenada Media Group.

Pearce II, John A. \& Richard B. Robinson. 2009. Manajemen Strategis: Formulasi, Impementasi, dan Pengendalian. Jakarta. Salemba empat.

Ratminto \& Winarsih, Atik Septi. 2006. Manajemen Pelayanan. Yogyakarta. Pustaka Pelajar.

Siagian P, Sondang. 1992. Kerangka Dasar Ilmu Administrasi. Jakarta. Rieneka Cipta.

Widyastuti R, Niken. 2005. Perubahan Status Radio Republik Indonesia Dari Radio Pemerintah Menjadi Lembaga Penyiaran Publik. Tesis. Universitas Gajah Mada.

Sugiyono. 2010. Memahami Penelitian Kualitatif. Bandung. CV.Alfabeta.

Stoner, A.F. James. 1999. Manajemen. Erlangga, Jakarta

Suara Publik. 2013. Mendukung LPP. Kompilasi Road Show, diskusi public RUU penyiaran 2013. Jakarta. Radio Republik Indonesia.

Taufiq Effendy. 2005. Arah Pembaharuan Pelayanan Publik. Makalah. Makalah dalam Workshop Forum Nasional Pemerintah Daerah Terobosan dan Inovasi Manajemen Pelayanan Publik yang diselenggarakan oleh FISIPOL Gadjah Mada.

Thoha, Miftah. 1991. Prespektif perilaku Birokrasi. Jakarta. CV. Rajawali. 
Panbudu Tika, Moh. 2010, Budaya Organisasi dan Peningkatan Kinerja Perusahaan. Jakarta. Bumi Aksara.

Widodo, Joko. 2001. Good Governance, Telaah dari Dimensi Akuntabilitas dan Kontrol Birokrasi Pada Era Desentralisasi dan Otonomi Daerah. Surabaya. Insan Cendekia.

Wibowo. 2005. Manajemen Perubahan Edisi Ketiga. Jakarta. PT.Raja Grafindo Persada.

Winardi, J. 2005. Manajemen perubahan (management of change). Jakarta. Kencana Prenada Media Group.

Hasan, Ikbal. 2002. Metodelogi penelitian kualitatif. Bandung. Ranaja Rosdakarya.

Hadi, Parni. 2007. Asal Diberi Kebebasan Berkreasi, Pasti Bisa Berubah. Diakses dari http://dimasnugraha.wordpress.com/2007/10/04/wwc-parni-hadi/. Pada tanggal 03 Maret 2016, Jam 23.00 WIB.

Wikipedia. 2014. Radio Republik Indonesia. Diakses dari http://id.wikipedia.org/wiki/Radio_Republik_Indonesia. Pada tanggal 09 Maret 2016, Jam 16.00 WIB.

Radio Republik Indonesia. Profil Radio Republik Indonesia. Diakses dari http://rri.co.id/index.php/profil\#.UvpFYmKSzLc. Pada tanggal 02 April 2016, Jam 14.00 WIB.

\section{Sumber Hukum:}

Undang-Undang Nomor 32 tahun 2002 tentang Penyiaran.

Peraturan Pemerintah Republik Indonesia nomer 37 tahun 2000, tentang pendirian Perusahaan Jawatan Radio Republik Indonesia.

Peraturan Pemerintah Republik Indonesia nomor 37 tahun 2000, tentang pendirian Perusahaan Jawatan Radio Republik Indonesia. 